\title{
Leptodora kindtii survival in the laboratory
}

\author{
Radka Pichlová $^{1,2, *}$, Anke Weber ${ }^{3,4}$ and Brigitte Gosser ${ }^{3}$ \\ ${ }^{1}$ Faculty of Biological Sciences, University of South Bohemia, Branišovská 3137005 České Budějovice, \\ Czech Republic; ${ }^{2}$ Current address: CILER, University of Michigan and Great Lakes Environmental Research \\ Laboratory/NOAA, 2205 Commonwealth Blvd. Ann Arbor, MI 48105, USA; ${ }^{3}$ Netherlands Institute of Ecology \\ (NIOO-KNAW), Centre for Limnology, Rijksstraatweg 6, 3631 AC Nieuwersluis, The Netherlands; ${ }^{4}$ Current \\ address: TNO Environment, Energy and Process Innovation, PO Box 57, 1780 AB Den Helder, The \\ Netherlands; *Author for correspondence (fax: +1-734-741-2055; e-mail: pichlova@umich.edu)
}

Received 15 April 2003; accepted in revised form 24 March 2004

Key words: Laboratory maintenance, Leptodora kindtii, Predatory cladoceran, Water quality

\begin{abstract}
Leptodora kindtii, a pelagic predatory cladoceran, suffers high mortality on transfer to laboratory, which makes the experimental work difficult. We investigated the causes of high mortality, using four variables: water volume, animal density, light intensity, and origin of water for culturing, i.e., water from native or a non-native lake. For the experiments we used Leptodora and water from Lake Loosdrecht and Lake Maarsseveen (The Netherlands). Water was found to be the most important factor; the animals did not necessarily do better in lake water from which they were collected. Water volume and animal density were of limited importance, and light intensity did not affect survival.
\end{abstract}

\section{Introduction}

The predatory cladoceran Leptodora kindtii is a large plankton species common in lakes of the Northern temperate zone (Rivier 1998). Its importance in food webs of lakes and reservoirs has been reported repeatedly (e.g., Lunte and Luecke 1990; Branstrator and Lehman 1991; Herzig 1994). However, detailed studies of its predatory behavior under controlled conditions are still scarce (Herzig and Auer 1990; Pichlova and Vijverberg 2001). Most of the workers have reported high mortality of animals under laboratory conditions (e.g., Mordukhai-Boltovskaya 1956; Havel 1985; Burkhardt and Lehman 1994), but cause of this is not known yet.

We used four parameters that we considered important for studying Leptodora survival: 1) volume of water in a beaker, 2) density of animals in a beaker, 3) light intensity, and 4) origin of culture water. Leptodora, being a large animal, is reported to need a large space for survival (Mordukhai-Boltovskaya 1957), though this has never been demonstrated. The highest densities in field samples reached is 2-3 ind./1 (Gulati et al. 1992), however, we do not know if crowding (physical contact of the animals) can influence survival. Regarding light, Leptodora is known to be positively light sensitive; it tends to move more actively in high light conditions (e.g., Herzig and Auer 1990; pers. observation). Finally, testing of water origin as a factor to concern was based on our previous preliminary experience. With this study we aim at investigating factors that can result in improved maintenance of Leptodora in laboratory for experimental work. 
Table 1. General parameters of Lakes Loosdrecht and Maarsseveen. References: ${ }^{1}$ Gulati et al. (1992), ${ }^{2}$ Hofstra and van Liere (1992), ${ }^{3}$ Kersting (1981), ${ }^{4}$ Swain et al. (1987), ${ }^{5}$ van Donk (1983), ${ }^{6}$ van Donk (1987), ${ }^{7}$ personal observation.

\begin{tabular}{|c|c|c|}
\hline Parameters & Lake Loosdrecht & Lake Maarsseveen \\
\hline Origin of lake & peat-digging $^{1}$ & peat-digging, later excavation of sand ${ }^{6}$ \\
\hline Area (ha) & $979^{1}$ & $70^{5}$ \\
\hline Mean depth (m) & $1.85^{1}$ & $12.1^{4}$ \\
\hline Main source of water & Amsterdam-Rhine canal ${ }^{2}$ & groundwater, seepage $^{4}$ \\
\hline Trophy & eutrophic $^{2}$ & meso-oligotrophic $^{6}$ \\
\hline Mean Secchi disc depth (m) & $0.3-0.5^{1}$ & $3.5-8^{4}$ \\
\hline Color of water & yellow-brown ${ }^{7}$ & transparent $^{7}$ \\
\hline $\mathrm{pH}$ (summer average) & $8.9^{2}$ & $8.2^{4}$ \\
\hline Total phosphorus $\left(\mathrm{mg} \mathrm{l}^{-1}\right)$ & $0.1^{2}$ & $0.02^{6}$ \\
\hline Salinity $\left(\mathrm{mg} \mathrm{l}^{-1}\right)$ & $305^{2}$ & $310^{4}$ \\
\hline Oxygen concentration $\left(\mathrm{mg} \mathrm{l}^{-1}\right)$ (summer average) & $10.4^{1}$ & $9.0(\text { in upper } 5 \mathrm{~m})^{3}$ \\
\hline Chlorophyll content $\left(\mu \mathrm{g}^{-1}\right)$ & $93 \pm 18^{1}$ & $0.5-4^{5}$ \\
\hline Average Leptodora density during summer season (ind. $1^{-1}$ ) & $0.5-1.5^{1}$ & $0.1^{7}$ \\
\hline
\end{tabular}

\section{Material and methods}

\section{Leptodora: collecting, keeping, and handling}

The animals and lake water were collected one day prior to experiments from two lakes in the vicinity of Nieuwersluis (The Netherlands): the eutrophic Lake Loosdrecht (LL) and the oligotrophic Lake Maarsseveen (LM); general limnological characteristics of the lakes are presented in Table 1. The experiments were carried out in August 1998. Leptodora were sampled using horizontal net hauls of two hoop plankton nets (mesh size $1 \mathrm{~mm}$ ) with 5 -1 plastic cod ends (a bottle attached to a narrow end of a plankton net), mounted on a pole, which was slowly towed through water (less than $1 \mathrm{~m} \mathrm{~s}^{-1}$ ) (Vijverberg 1991), and then transferred carefully to the laboratory directly in the cod ends. The samples were diluted with water from the corresponding lake, and Leptodora were acclimated to lab conditions without food for $24 \mathrm{hrs}$ in rectangular 25-1 glass aquaria. To prevent Leptodora from continuously striking against the aquaria walls, especially corners, the vessels were kept under low and diffused light $\left(0.07 \mu \mathrm{mol} \mathrm{m} \mathrm{m}^{-2}\right.$ $\mathrm{s}^{-1}$ ), at 16:8 hrs light and dark, and the corners of aquaria were covered with black foil. The acclimation temperature $\left(17.5 \pm 1{ }^{\circ} \mathrm{C}\right)$ was similar to that in the lakes. Oxygen concentration in the aquaria did not decrease below $90 \%$ of its initial concentration; the lowest concentration measured was $8.5 \mathrm{mg} \mathrm{O}_{2} \mathrm{I}^{-1}$.

\section{Experimental design}

The acclimated Leptodora were transferred to beakers filled with filtered lake water $(0.45 \mu \mathrm{m}$ membrane filter; Schleicher and Schuell) using a wide-mouth pipette. The animals were not fed during the experiments. Although the starvation is likely to decrease the survival time, we decided not to feed the animals to ascertain that all animals were under similar conditions during the experiments. Leptodora feed discontinuously, and their foraging success depends on the capture rate and handling time of the prey. Consequently, the presence of prey and differential feeding ability can affect the outcome of the experiments. We used only adult females, i.e., mature animals measuring at least $5.0-6.5 \mathrm{~mm}$ in length (Andrews 1953). To avoid the release of newborns during the experiment, only females without brood or with early stage eggs were used. The experiments lasted for 72 or $84 \mathrm{hrs}$, during which the animals were checked every $12 \mathrm{hrs}$ for survival. An overview of the performed experiments and tested treatments is shown in Table 2. The design was partially crossed.

\section{Statistical analysis}

We used a sample comparing function in a survival analysis module of the Statistica package (Statsoft Inc. 1995) for analyzing differences in surviving pattern among treatments. This method considers: (1) that some of the animals were still alive at the end of the experiment ( 72 or $84 \mathrm{hrs}$ ), and that their survival time was unknown (so called 'censored'), and (2) that others died during the experimental period and their 
Table 2. Overview of all experiments done. Numbers of replicates per treatment are given.

\begin{tabular}{|c|c|c|c|c|c|c|}
\hline \multirow[b]{4}{*}{ Tested factor } & \multirow[b]{4}{*}{ Treatment } & \multicolumn{4}{|c|}{ Leptodora origin } & \multirow[b]{4}{*}{ Parameters kept constant } \\
\hline & & \multirow{2}{*}{\multicolumn{2}{|c|}{$\frac{\text { Loosdrecht }}{\text { Water origin }}$}} & \multirow{2}{*}{\multicolumn{2}{|c|}{$\frac{\text { Maarsseveen }}{\text { Water origin }}$}} & \\
\hline & & & & & & \\
\hline & & Loosdrecht & Maarsseveen & Loosdrecht & Maarsseveen & \\
\hline \multirow[t]{4}{*}{ Volume (ml) } & 100 & 15 & 33 & - & - & \multirow{4}{*}{$\begin{array}{l}\text { Leptodora density (= } 1 \text { ind.) } \\
\text { Light intensity (= 16h L:8h D } \\
\text { high) }\end{array}$} \\
\hline & 250 & 18 & 33 & - & 32 & \\
\hline & 500 & 10 & 20 & - & - & \\
\hline & 800 & 10 & 20 & - & 12 & \\
\hline \multirow{5}{*}{$\begin{array}{l}\text { Leptodora } \\
\text { density (\# of ind. } \\
\text { in beaker) }\end{array}$} & 1 & 10 & 20 & - & 12 & \multirow{5}{*}{$\begin{array}{l}\text { Volume }(=800 \mathrm{ml}) \text { Light } \\
\text { intensity (= } 16 \mathrm{~h} \mathrm{~L}: 8 \mathrm{~h} \mathrm{D} \mathrm{high})\end{array}$} \\
\hline & 5 & 3 & 5 & - & 3 & \\
\hline & 10 & 3 & 4 & - & 3 & \\
\hline & 15 & 3 & 4 & - & 3 & \\
\hline & 20 & 3 & 4 & - & 2 & \\
\hline \multirow[t]{5}{*}{ Light intensity } & No light & 8 & 21 & - & 8 & \multirow{5}{*}{$\begin{array}{l}\text { Leptodora density (= } 1 \text { ind.) } \\
\text { Volume }(=250 \mathrm{ml})\end{array}$} \\
\hline & 16h L:8h D low & 8 & 21 & - & 8 & \\
\hline & 8h L:16h D high & 8 & 21 & - & - & \\
\hline & 16h L:8h D high & 6 & 21 & - & 8 & \\
\hline & Permanent high & 8 & 14 & - & 8 & \\
\hline \multicolumn{2}{|l|}{ Water origin } & 20 & 20 & 20 & 22 & $\begin{array}{l}\text { Leptodora density }(=1 \text { ind.) } \\
\text { Volume }(=250 \mathrm{ml}) \text { Light } \\
\text { intensity (= } 16 \mathrm{~h} \mathrm{~L}: 8 \mathrm{~h} \mathrm{D} \mathrm{high)}\end{array}$ \\
\hline
\end{tabular}

survival time was known (uncensored). To compare more than two treatments within an experiment we performed a nonparametric multiple-sample test, while Cox's $F$-test (recommended as best for relatively small $n$, Statsoft Inc. 1995) was applied for comparing only two treatments. The Cox's $F$-test was used also for a post-hoc comparison of pairs of treatments within a tested factor when the multiple-sample test showed a significant difference. In the density experiment, the three to five replicates of 5, 10, 15 and 20 animals were pooled for analysis; in all other experiments all observations within one treatment represented one pool.

\section{Results}

Survival of Leptodora from Lake Loosdrecht was not significantly affected by water volume in either Lake Loosdrecht water (LLW) (Table 3, Figure 1a) or in Lake Maarsseveen water (LMW) (Table 3, Figure 1c). However, Leptodora from Lake Maarsseveen survived in LMW significantly better in $800 \mathrm{ml}$ than in $250 \mathrm{ml}$ (Table 3, Figure 1b).
The analysis of density experiments revealed significant dissimilarity among treatments in sets with animals kept in their native water (Table 3, Figure $2 \mathrm{a}, \mathrm{b})$. Though the post-hoc pair comparison within these sets resulted in several significant differences, we could not conclude if density affected survival (Table 4). The survival of Leptodora from LL in LMW was similar at all densities (Table 3, Figure 2c).

Light intensity had no significant effect on Leptodora survival (Table 3, Figure 3), irrespective of Leptodora and lake water in the treatment.

Water origin appeared to be an important variable for Leptodora survival. Leptodora from LL survived significantly longer in LLW than in LMW (Table 3). Only a few animals from LL died in their original water within the first $36 \mathrm{hrs}$. In contrast, in LMW there was nearly $90 \%$ mortality of LL animals under similar duration (Figure 4). The survival significantly differed also for Leptodora from LM exposed to LLW and LMW, respectively (Table 3, Figure 4). Surprisingly, Leptodora from LM survived longer in LLW than in their native LM water. There was no significant difference in survival between LL and LM Leptodora in Lake Loosdrecht water (Figure 4), while in 

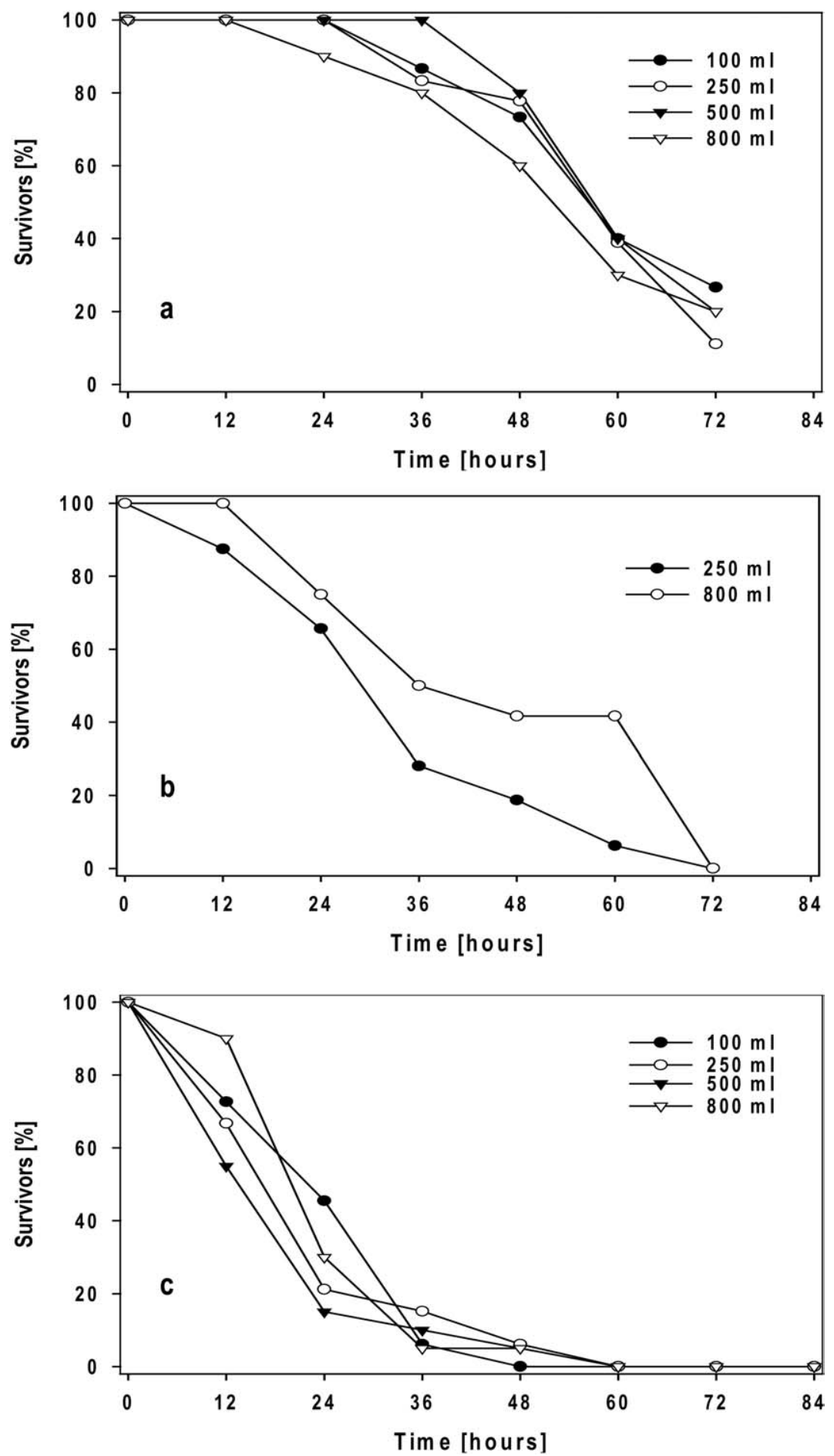

Figure 1. Volume effect: single Leptodora in water volumes of $100 \mathrm{ml}, 250 \mathrm{ml}, 500 \mathrm{ml}$ and $800 \mathrm{ml}$ in $1000 \mathrm{ml}$ beakers. Leptodora from Lake Loosdrecht in Lake Loosdrecht water (a), Leptodora from Lake Maarsseveen in Lake Maarsseveen water (b), Leptodora from Lake Loosdrecht in Lake Maarsseveen water (c). 
Table 3. Results of survival statistical analysis for studied effects. (LL - Lake Loosdrecht, LM - Lake Maarsseveen). 'Uncensored' number of observations means number of animals dead by the last counting, while animals 'censored' were still alive at the moment of the last counting.

\begin{tabular}{|c|c|c|c|c|c|c|c|c|c|}
\hline \multirow[t]{2}{*}{ Effect } & \multirow[t]{2}{*}{ Leptodora } & \multirow[t]{2}{*}{ Water } & \multicolumn{3}{|c|}{ Number of observations } & \multirow[t]{2}{*}{ d.f. } & \multirow[t]{2}{*}{$x^{2}$} & \multirow[t]{2}{*}{$\mathrm{F}$} & \multirow[t]{2}{*}{$\mathrm{P}$} \\
\hline & & & Total & Uncensored & Censored & & & & \\
\hline \multirow[t]{4}{*}{ Volume } & \multirow[t]{2}{*}{ LL } & LLW & 53 & 43 & 10 & 3 & 1.08 & & 0.783 \\
\hline & & LMW & 106 & 105 & 1 & 3 & 5.27 & & 0.153 \\
\hline & \multirow[t]{2}{*}{$\mathrm{LM}$} & LLW & - & & & & & & \\
\hline & & LMW & 44 & 43 & 1 & 0 & & 2.11 & 0.027 \\
\hline \multirow[t]{4}{*}{ Density } & \multirow[t]{2}{*}{ LL } & LLW & 160 & 157 & 3 & 4 & 16.38 & & 0.003 \\
\hline & & LMW & 225 & 218 & 7 & 4 & 0.66 & & 0.956 \\
\hline & \multirow[t]{2}{*}{ LM } & LLW & - & & & & & & \\
\hline & & LMW & 142 & 130 & 12 & 4 & 13.98 & & 0.007 \\
\hline \multirow[t]{4}{*}{ Light } & \multirow[t]{2}{*}{ LL } & LLW & 38 & 36 & 2 & 4 & 5.75 & & 0.219 \\
\hline & & LMW & 98 & 89 & 9 & 4 & 4.84 & & 0.304 \\
\hline & \multirow[t]{2}{*}{$\mathrm{LM}$} & LLW & - & & & & & & \\
\hline & & LMW & 32 & 32 & 0 & 3 & 4.16 & & 0.245 \\
\hline \multirow[t]{2}{*}{ Water } & LL & $\begin{array}{l}\text { LLW } \\
\text { LMW }\end{array}$ & 40 & 39 & 1 & 0 & & 4.62 & $<0.001$ \\
\hline & LM & $\begin{array}{l}\text { LLW } \\
\text { LMW }\end{array}$ & 42 & 40 & 2 & 0 & & 2.61 & 0.018 \\
\hline
\end{tabular}

Lake Maarsseveen water LM Leptodora survived better than animals from LL.

\section{Discussion}

The lack of a hard carapace makes Leptodora very vulnerable to handling and manipulation. Their high mortality in laboratory is probably largely caused by cumulative stress of collection and transfer. We hypothesize though that one or more key factors of the laboratory environment are crucial for extension of Leptodora survival. In general, the rather short total period of survival (max. 4.5 days incl. acclimation period) in our experiment could have been negatively affected by starving. Nevertheless, under the similar handling and starvation conditions, the survival of the animals differed for different manipulated factors.

It is surprising that light intensity did not produce any effects, since published reports (Andrews 1953; Wolken and Gallik 1965) and our unpublished data suggest that light is an important factor in Leptodora activity. However, we did not observe that enhanced activity at higher light intensities would decrease the survival of the animals. We did not, however, investigate the effect of qualitative characteristics of light on Leptodora. Contrary to a common assumption that large animals like Leptodora would do better in larger volume and lower density, we did not find any strong evidence for it.

The effect of water origin (Figure 4) was strong in all experiments, including those focused primarily on factors other than origin of water. Irrespective of differences within the tested treatments, the overall shape of survival curves followed similar patterns based on used Leptodora and lake water (Figure 1-3). Our finding on the effect of water type is significant, more so because survival of Leptodora in water from lake of its origin was not necessarily higher. On the contrary, Leptodora originating from Lake Maarsseveen survived better in water from Lake Loosdrecht than in lake water of its origin. Water from the same lake as the tested animal is generally considered to be the best medium for any experimental work (Peters and de Bernardi 1987). Here we show that for Leptodora it is not always true, and that one should consider use of water from non-native lake(s) for better survival. The filtered Lake Loosdrecht water obviously contains some substances that keep Leptodora longer alive in the laboratory, regardless of animals' origin, while Lake Maarsseveen lacks that. Such a substance from LLW needs to be identified in future studies.

We are aware that water quality data for Lakes Loosdrecht and Maarsseveen (Table 1) are rather limited and not from the period of our Leptodora study. Therefore, we can only speculate about 



Figure 2. Density effect: densities of 1, 5, 10, 15 and 20 individuals in $800 \mathrm{ml}$ of water. Leptodora from Lake Loosdrecht in Lake Loosdrecht water (a), Leptodora from Lake Maarsseveen in Lake Maarsseveen water (b), Leptodora from Lake Loosdrecht in Lake Maarsseveen water (c). 

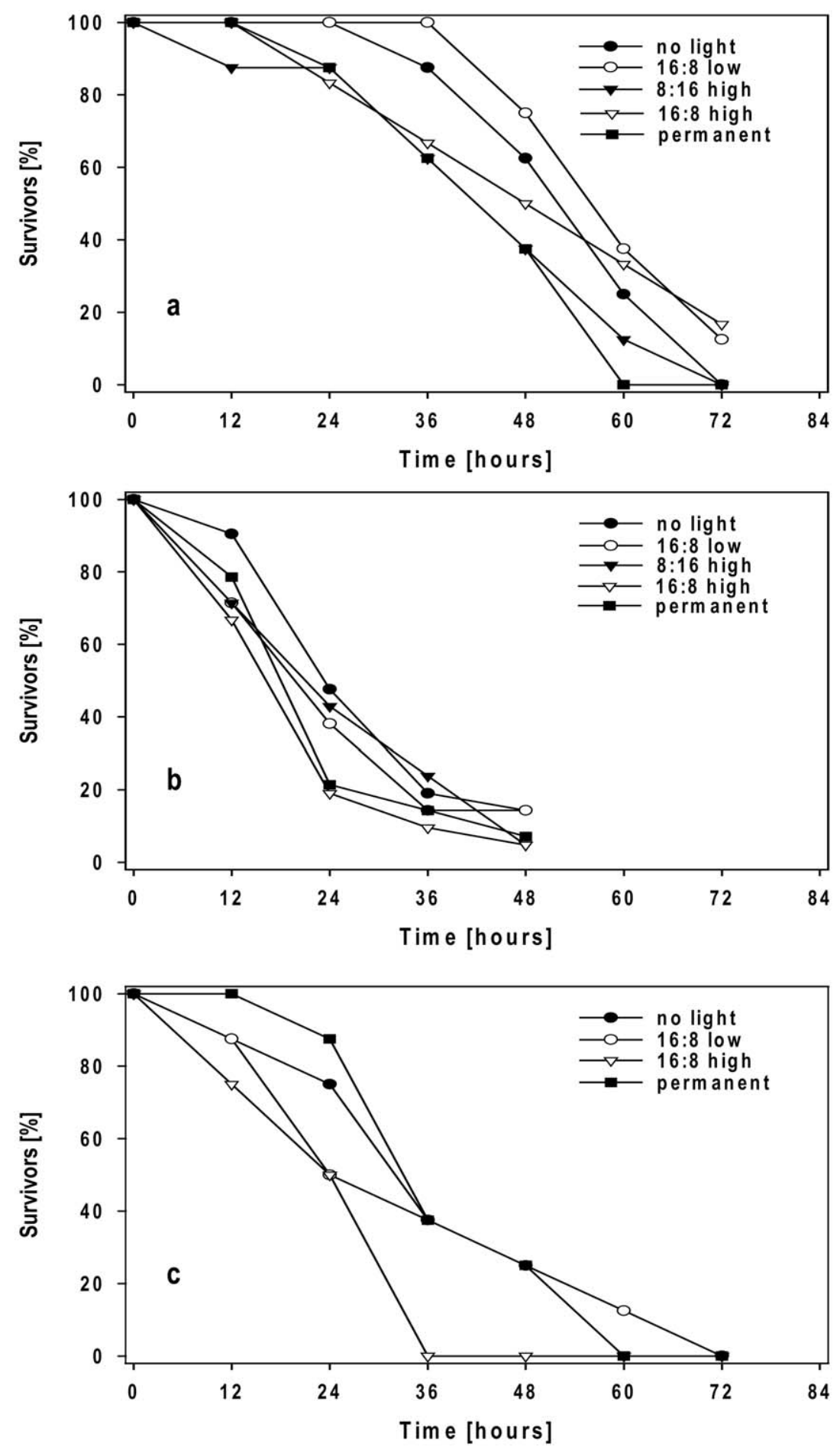

Figure 3. Light effect: single Leptodora in five levels of light intensity (no light, $16 \mathrm{~h} \mathrm{~L}: 8 \mathrm{~h} \mathrm{D} \mathrm{low} \mathrm{light}\left(0.07 \mu \mathrm{mol} \mathrm{m}^{-2} \mathrm{~s}^{-1}\right)$, $8 \mathrm{~h} \mathrm{L:16h} \mathrm{D} \mathrm{high}$ intensity light $\left(10.3 \mu \mathrm{mol} \mathrm{m}{ }^{-2} \mathrm{~s}^{-1}\right), 16 \mathrm{~h} \mathrm{~L}: 8 \mathrm{~h} \mathrm{D}$ high intensity light $\left(10.3 \mu \mathrm{mol} \mathrm{m}^{-2} \mathrm{~s}^{-1}\right)$, permanent high intensity light $\left(10.3 \mu \mathrm{mol} \mathrm{m}{ }^{-2} \mathrm{~s}^{-1}\right)$. Leptodora from Lake Loosdrecht in Lake Loosdrecht water (a), Leptodora from Lake Maarsseveen in Lake Maarsseveen water (b), Leptodora from Lake Loosdrecht in Lake Maarsseveen water (c). 
Table 4. Post-hoc pair comparison of density experiments, which showed statistically significant dissimilarity. UnC $=$ uncensored, $\mathrm{C}=$ censored.

\begin{tabular}{|c|c|c|c|c|c|c|c|c|c|c|}
\hline \multirow[t]{3}{*}{ Density treatments pairs tested } & \multicolumn{5}{|c|}{ LL Leptodora in LL water } & \multicolumn{5}{|c|}{ LM Leptodora in LM water } \\
\hline & \multicolumn{3}{|c|}{ Number of observations } & \multirow[t]{2}{*}{$\mathrm{F}$} & \multirow[t]{2}{*}{$\mathrm{P}$} & \multicolumn{3}{|c|}{ Number of observations } & \multirow[t]{2}{*}{$\mathrm{F}$} & \multirow[t]{2}{*}{$\mathrm{P}$} \\
\hline & Total & UnC & $\mathrm{C}$ & & & Total & $\mathrm{UnC}$ & $\mathrm{C}$ & & \\
\hline $1 \times 5$ & 25 & 22 & 3 & 1.80 & 0.072 & 25 & 23 & 2 & 1.23 & 0.217 \\
\hline $1 \times 10$ & 40 & 38 & 2 & 1.40 & 0.160 & 42 & 41 & 1 & 1.09 & 0.277 \\
\hline $1 \times 15$ & 55 & 53 & 2 & 2.69 & 0.007 & 57 & 51 & 6 & 0.36 & 0.719 \\
\hline $1 \times 20$ & 70 & 68 & 2 & 2.74 & 0.006 & 52 & 45 & 7 & 0.77 & 0.439 \\
\hline $5 \times 10$ & 45 & 44 & 1 & 1.33 & 0.185 & 45 & 45 & 0 & 0.66 & 0.509 \\
\hline $5 \times 15$ & 60 & 59 & 1 & 0.85 & 0.395 & 60 & 55 & 5 & 1.36 & 0.175 \\
\hline $5 \times 20$ & 75 & 74 & 1 & 1.00 & 0.316 & 55 & 49 & 6 & 2.97 & 0.003 \\
\hline $10 \times 15$ & 75 & 75 & 0 & 2.68 & 0.007 & 75 & 70 & 5 & 0.89 & 0.372 \\
\hline $10 \times 20$ & 90 & 90 & 0 & 2.90 & 0.004 & 70 & 64 & 6 & 3.21 & 0.001 \\
\hline $15 \times 20$ & 105 & 105 & 0 & 0.09 & 0.93 & 85 & 74 & 11 & 2.26 & 0.024 \\
\hline
\end{tabular}

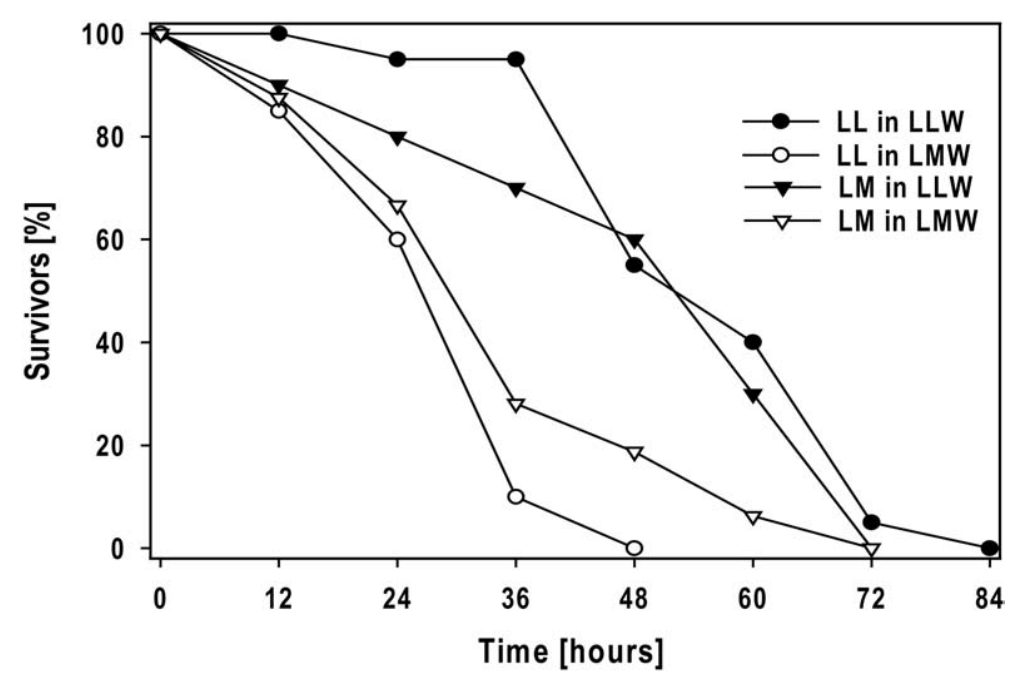

Figure 4. Water effect: single Leptodora originated either from Lake Loosdrecht (LL) or Lake Maarsseveen (LM) kept in water from Lake Loosdrecht (LLW) or from Lake Maarsseveen (LMW).

possible causes of the differences in Leptodora survival due to water quality differences in the two lakes. Lakes Loosdrecht and Maarsseveen differ greatly from one another in trophic states: in total phosphorus, chlorophyll content and Secchi disc depth (Table 1 ), and are therefore also likely to differ in contents of dissolved organic matter (DOM) and particulate organic matter (POM). Kulikov et al. (1992) suggested that Leptodora might possibly absorb some DOM through penetration across the very thin body surface. This would supplement the carbon (= energy) in the starving animals, here much more in Lake Loosdrecht than in Lake Maarsseveen water. Lake Loosdrecht has higher dissolved organic material mainly due to more dissolved humic acids. The humic acids may have some buffering activity or may sequester some substances including nutrients $(\mathrm{Gu}-$ lati, pers. comm.), and therefore influence qualities of water important for better Leptodora survival. These hypotheses, however, require further testing.

Because the salinity and $\mathrm{pH}$ differences between the lakes (Table 1) are minimal they do not help us to explain the discrepancies in survival rates. Oxygen is another potentially inconsistent parameter. Moshiri et al. (1969) had reported that below $8 \mathrm{mg} \mathrm{l}^{-1}$, the animals are stressed or at least abnormally inactive. Though we did not continuously monitor the oxygen concentration in the acclimation aquaria for Leptodora, oxygen concentrations were not lower than $8.5 \mathrm{mg} \mathrm{O}_{2} \mathrm{1}^{-1}$. Moreover, the experiments were car- 
ried out at a medium temperature $\left(17.5 \pm 1{ }^{\circ} \mathrm{C}\right)$, which makes oxygen depletion less likely.

The response of the Leptodora populations from two lakes to origin of water and density differed possibly because of differences in genetic, population-related characteristics of these populations. The genotype-related differences in phenotypic response to some stress has been documented several times in filter-feeding cladocerans (e.g., Bachiorri et al. 1991; Epp 1996; Weber and Declerck 1997; Barata et al. 2000). Therefore, the success of keeping Leptodora in the lab might also depend on the characteristics of the source population and not only on culture conditions.

\section{Conclusions}

We found that the culture water used is an important factor for survival of starved Leptodora in the laboratory, though obviously no clear-cut explanations can be given for the observed differences in mortality rate. Water volume and density of animals were of a limited importance and light intensity seemed to play no significant role.

\section{Acknowledgements}

We thank Peter Mac Gillavry for help with the collection of Leptodora and water. Thanks for valuable comments by Hank Vanderploeg, Joann Cavaletto, Cathy Darnell, Ramesh Gulati, Ellen van Donk, and the anonymous reviewers. R. P. acknowledges financial support by the Open Society Fund (Czech Republic), NUFFIC (The Netherlands) and the Czech Literary Fund (Czech Republic). B. G. was supported by a grant of the 'Deutsche Forschungsgemeinschaft' (Germany). This is GLERL contribution \# 1314 and publication 3355 NIOO-KNAW.

\section{References}

Andrews T.F. 1953. Growth studies on parthenogenetically produced male and female Leptodora kindtii (Focke). Trans Amer. Microsc. Soc. 72: 9-17.

Bachiorri A., Rossi V. and Menozzi P. 1991. Differences in demographic parameters among electrophoretic clones of Daphnia obtusa Kurz (Crustacea, Cladocera). Hydrobiologia 225: 263268 .
Barata C., Baird D.J., Amat F. and Soares A.M. 2000. Comparing population response to contaminants between laboratory and field: an approach using Daphnia magna ephippial egg banks. Funct. Ecol. 14: 513-523.

Branstrator D.K. and Lehman J.T. 1991. Invertebrate predation in Lake Michigan: regulation of Bosmina longirostris by Leptodora kindtii. Limnol. Oceanogr. 36: 483-495.

Burkhardt S. and Lehman J.T. 1994. Prey consumption and predatory effects of an invertebrate predator (Bythotrephes, Cladocera, Cercopagidae) based on phosphorus budgets. Limnol. Oceanogr. 39: 1007-1019.

Epp G.T. 1996. Clonal variation in the survival and reproduction of Daphnia pulicaria under low-food stress. Freshw. Biol. 35: $1-10$.

Gulati R.D., Ooms-Wilms A.L., Van Tongeren O.F., Postema G. and Siewertsen K. 1992. The dynamics and role of limnetic zooplankton in Loosdrecht Lakes (The Netherlands). Hydrobiologia 233: 69-86.

Havel J.E. 1985. Predation of common invertebrate predators on long-featured and short-featured Daphnia retrocurva. Hydrobiologia 124: 141-149.

Herzig A. 1994. Predator-prey relationships within the pelagic community of Neusiedler See. Hydrobiologia 276: 81-96.

Herzig A. and Auer B. 1990. The feeding behaviour of Leptodora kindti and its impact on the zooplankton community of Neusiedler See (Austria). Hydrobiologia 198: 107-117.

Hofstra J.J. and van Liere L. 1992. The state of the environment of the Loosdrecht Lakes. Hydrobiologia 233: 11-20.

Kersting K. 1981. Annual and diel oxygen and temperature regime of the Lakes Maarsseveen. Hydrobiol. Bull. 15: 10-28.

Kulikov A.S., Shkute A.O. and Polishchuk L.V. 1992. Feeding in juvenile Leptodora kindti (Focke) (Crustacea, Cladocera). Soviet J. Ecol. 22: 202-205.

Lunte C.C. and Luecke C. 1990. Trophic interactions of Leptodora in Lake Mendota. Limnol. Oceanogr. 35: 1091-1100.

Mordukhai-Boltovskaya E.D. 1956. Some notes of the biology of Leptodora kindtii Focke and Bythotrephes Leydig from the Rybinsk Reservoir. Dokl. Akad. Nauk SSSR 110: 688-691.

Mordukhai-Boltovskaya E.D. 1957. Parthenogenic breeding of Leptodora kindtii (Focke) and Bythotrephes Leydig. Dokl. Akad. Nauk SSSR 112: 1133-1135.

Moshiri G.A., Cummins K.W. and Costa R.R. 1969. Respiratory energy expenditure by the predaceous zooplankter Leptodora kindtii (Focke) (Crustacea: Cladocera). Limnol. Oceanogr. 14: 475-484.

Peters R.H. and De Bernardi R. 1987. Daphnia. Memorie Dell'Istituto Italiano Di Idrobiologia. 45, Verbania Pallanza, Italy.

Pichlova R. and Vijverberg J. 2001. A laboratory study of functional response of Leptodora kindtii to some cladoceran species and copepod nauplii. Arch. Hydrobiol. 150: 529-544.

Rivier I.K. 1998. The predatory Cladocera (Onychopoda: Podonidae, Polyphemidae, Cercopagidae) and Leptodorida of the world. Backhuys Publishing, Leiden, The Netherlands.

Statsoft Inc. 1995. Statistica for Windows, ver. 5.0. StatSoft, Inc. 2325 East 13th Street, Tulsa OK 74104, USA.

Swain W.R., Lingeman R. and Heinis F. 1987. A characterization and description of the Maarsseveen Lake system. Hydrobiol. Bull. 21: 5-16. 
van Donk E. 1983. Factors influencing phytoplankton growth and succession in Lake Maarsseveen. $\mathrm{PhD}$ thesis, Universiteit van Amsterdam, The Netherlands.

van Donk E. 1987. The water quality of the two Maarsseveen Lakes in relation to their hydrodynamics. Hydrobiol. Bull. 21: 17-24.

Vijverberg J. 1991. Variability and possible adaptive significance of day-time vertical distribution of Leptodora kindtii (Focke)
(Cladocera) in a shallow eutrophic lake. Hydrobiol. Bull. 25: 85-91.

Weber A. and Declerck S. 1997. Phenotypic plasticity of Daphnia life-history traits in response to predator kairomones - genetic variability and evolutionary potential. Hydrobiologia 360: 89-99.

Wolken J.J. and Gallik G.J. 1965. The compound eye of a crustacean, Leptodora kindtii. J. Cell Biol. 26: 968-973. 